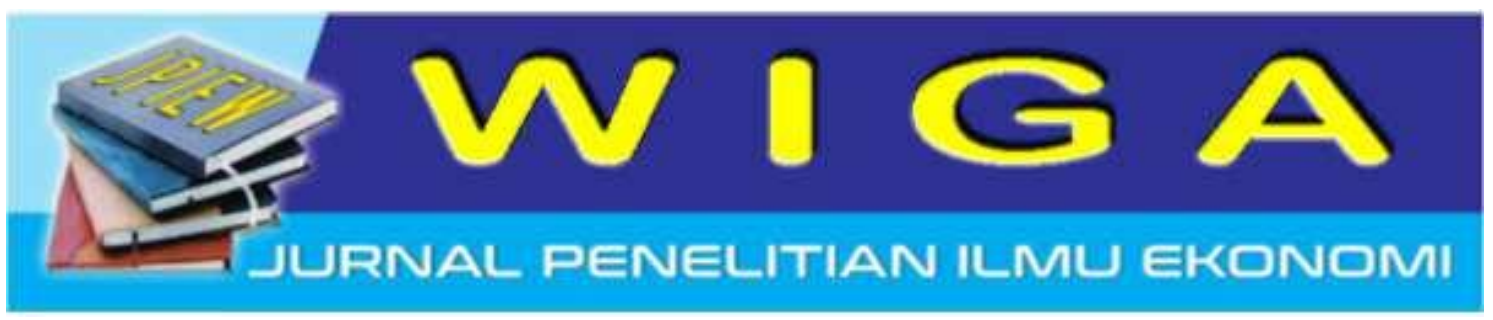

\title{
Pengaruh Kualitas Produk, Harga, Dan Citra Merek Terhadap Keputusan Pembelian Produk Madlyson Di Distro Aztekline Tulungagung
}

\author{
Rizkhi Sumarsono ${ }^{1}$, Achmad Firdiansjah ${ }^{2}$, Harianto Respati ${ }^{3}$ \\ Mahasiswa Program Magister Manajemen, Universitas Merdeka Malang, Indonesia \\ Email: rizkhisumar@yahoo.com
}

\begin{abstract}
This study aims to describe each variable, analyze the effect of product quality, price, and brand image of influence on the intention of purchasing decision of Madlyson product, and analyze the dominant variable affecting purchase decision at Aztekline store in Tulungagung. This study was processed using quantitative approach with survey method, sampling was 60 respondents. Data were collected through observation and documentation. Hypothesis testing used multiple linear regression analysis techniques, including multiple correlation coefficient, multiple determination coefficient and $\mathrm{t}$ test (partial) and $\mathrm{F}$ (simultaneous) test. Then, the data obtained will be analyzed using SPSS software version 16 (Statistics Package for Social Sciences). Analyzer used consisted of: Analysis of validity and reliability, Test of Classic Assumption, Normality Test, Multicollinearity Test, Heteroskidastity Test. The results of the analysis show that product quality, price, and brand image simultaneously affect the purchase decision of the product. Partially, all independent variables significantly affect purchasing decisions. The dominant variable is the brand image $(56.8 \%)$. The coefficient of determination (R2) shows that the independent variables studied can contribute to the dependent variable of $46.3 \%$ while the remaining $53.7 \%$ due to the contribution of outside research variables.
\end{abstract}

Keywords: product quality, price, brand image, purchase decision

\section{PENDAHULUAN}

Di era globalisasi persaingan dalam dunia usaha semakin ketat. Kondisi pasar yang kompetitif dan dinamis akan mengakibatkan setiap perusahaan harus selalu mengamati persaingan dalam bisnisnya. Dalam menghadapi lingkungan persaingan yang semakin kuat dan ketat, setiap perusahaan dituntut harus mampu mengoptimalkan sumberdayanya guna meningkatkan daya saing produknya dipasar, serta mampu menjalankan serangkaian strategi pemasaran tersebut secara terus menerus serta berkelanjutan. Pemasaran merupakan ujung tombak keberhasilan perusahaan dalam usaha untuk menjual serta meningkatkan nilai perusahaan di mata konsumen terhadap produk atau jasa yang dihasilkannya, hal ini dikarenakan dengan menciptakan nilai serta memuaskan konsumen merupakan konsep inti pemikiran pemasaran.
Setiap perusahaan dituntut selalu berusaha bekerja keras dalam berinovasi terhadap produk maupun jasanya agar mampu bertahan dari persaingan dan mampu menarik perhatian dari calon konsumen akan produk yang ditawarkan. Namun hal ini yang perlu diperhatikan dalam menjalankan bisnis usaha clothing. Sebelum merancang inovasi, perusahaan harus jelas terlebih dahulu mengetahui segmentasi pasar dan mana target yang akan disasar, dengan tujuan agar produk tersebut dapat dikenal oleh masyarakat.

Dari tahun ke tahun produk pakaian meningkat dengan sangat pesat, banyak merek-merek baru mulai bermunculan, sehingga membuat persaingan dalam bidang clothing semakin tinggi. Sehingga perusahaan clothing dituntut membuat produk yang berinovasi tinggi dan menentukan strategi pemasaran yang digunakannya untuk 
menghadapi persaingan yang ada saat ini. Bisnis clothing merupakan bisnis yang memiliki peluang tinggi untuk menghasilkan keuntungan sehingga banyak yang meminati untuk melakukan bisnis ini.

Usaha bisnis clothing lebih menuntut perusahaan untuk lebih kreatif agar konsumen selalu berminat untuk membeli produknya. Selain itu perusahaan juga dituntut lebih untuk mengetahui perilaku konsumen pada pasar sasarannya dengan menawarkan atau menjual produk yang berkualitas disertai pelayanan yang baik kepada pelanggan. Perusahaan harus mampu mengenal apa yang menjadi kebutuhan dan harapan konsumen saat ini maupun yang akan datang.

Pada penelitian ini, memilih lokasi di Distro "Aztekline". Aztekline merupakan salah satu distro di Tulungagung yang menjual berbagai produk clothing atau merek diantaranya Madlyson, Inspired, Warlock, Waspish, Heaven hearth, dll. Selain itu di Aztekline juga menjual perlengkapan skate mulai dari papan, roda, griptape, dll. Pada saat ini distro di Tulungagung sudah lumayan banyak, akan tetapi untuk distributor produk Madlyson yang di Tulungagung hanya berada di Aztekline.

Madlyson merupakan merek suatu produk clothing yang berasal dari Tulungagung, Jawa timur. Madlyson mempunyai beraneka ragam produk yang ditawarkan, diantaranya yaitu kaos, kemeja, celana, jaket, topi, dll, yang mempunyai kualitas produk yang cukup terjamin dengan harga yang bervariatif dapat dijangkau oleh kalangan anak muda. Pada saat ini penjualan Madlyson mengalami penurunan, karena adanya pesaing yang semakin tinggi.

Seiring perkembangan clothing yang semakin tinggi dapat mempengaruhi konsumen dalam keputusan untuk melakukan pembelian, yang berakibat secara tidak langsung dapat mempengaruhi kenaikan maupun penurunan dalam penjualan. Dimana keputusan pembelian pembelian konsumen dipengaruhi oleh informasi mengenai produk tersebut. Salah satunya yaitu kualitas produk, karena kualitas produk meyakinkan konsumen bahwa produk yang terbaik menurut kebutuhan konsumen. Kualitas produk sebagai penentu kepuasan yang diperoleh konsumen dalam melakukan pembelian dan pemakaian.
Hasil penelitian Gita (2014), kualitas produk berpengaruh signifikan terhadap keputusan pembelian konsumen di Matahari Department Store Manado. Produk yang berkualitas akan meningkatkan keputusan pembelian konsumen terutama untuk menggunakan produk tersebut.

Selain kualitas produk, harga juga merupakan faktor yang mempengaruhi konsumen dalam mengambil keputusan pembelian, karena mayoritas konsumen menentukan keputusan dalam pembelian terlebih dahulu yang dilihat adalah harga, harga tersebut sesuai apa tidak dengan tingkat perekonomian konsumen. Penentuan harga yang tepat akan sangat berpengaruh terhadap persepsi konsumen akan nilai produk yang dibeli. Sedangkan persepsi harga berkaitan dengan bagaimana informasi harga dipahami seluruhnya oleh konsumen dan memberikan makna yang dalam bagi konsumen.

Hasil penelitian Jopie (2015), harga berpengaruh signifikan terhadap keputusan pembelian konsumen di Bengkel Gaoel Manado Town Square. Hasil penelitian ini menjelaskan bahwa harga yang ditawarkan tokodapat diterima dan dapat dijangkau oleh konsumen dari berbagai kalangan konsumen sendiri mempunyai nilai tersendiri dari harga yang ditawarkan, konsumen bukan hanya melihat dari berapa banyak uang yang telah dibayarkan akan tetapi konsumen juga memberi penilaian dari segi kualitas produk dan pelayanan yang diberikan kepada konsumen.

Sampai saat ini produk Madlyson sudah cukup dikenal sebagian oleh kalangan anak muda kususnya di Tulungagung dengan logonya huruf $\mathrm{m}$ miring didalam lingkaran. Untuk kualitasnya cukup memadai misalnya mulai dari bahan kain, sablon dan lain-lain bisa dibilang lumayan bagus, dan untuk harganya tidak terlalu mahal hampir sama dengan produk-produk atau merek lain. Maka dalam penelitian ini peneliti tertarik untuk menguji atau menganalisis Pengaruh Kualitas Produk, Harga, dan Citra Merek Terhadap Keputusan Pembelian Produk Madlyson di Distro Aztekline Tulungagung.

Berdasarkan latar belakang diatas, maka peneliti merumuskan permasalahan sebagai berikut: 
1. Bagaimana deskripsi kualitas produk, harga, citra merek, dan keputusan pembelian produk?

2. Bagaimana pengaruh kualitas produk, harga, dan citra merek terhadap keputusan pembelian produk?

3. Mana diantara variabel kualitas produk, harga, dan citra merek yang berpengaruh dominan terhadap keputusan pembelian produk?

Serta tujuan penelitian sebagai berikut :

1. Untuk mendeskripsikan kualitas produk, harga, citra merek, dan keputusan pembelian produk Madlyson di Aztekline Tulungagung.

2. Untuk menganalisis pengaruh kualitas produk, harga, dan citra merek terhadap keputusan pembelian produk Madlyson di Aztekline Tulungagung.

3. Untuk menganalisis variabel kualitas produk, harga, dan citra merek yang berpengaruh dominan terhadap keputusan pembelian produk Madlyson di Aztekline Tulungagung.

\section{KAJIAN LITERATUR}

\section{A. Keputusan Pembelian}

1) Pengertian Keputusan Pembelian

Keputusan pembelian merupakan tahap dari proses pembelian yaitu ketika konsumen benar-benar membeli produk. Dimana konsumen mengenali masalahnya, mencari informasi mengenai produk atau merek tertentu dan mengevaluasi seberapa baik masingmasing pilihan tersebut dapat memecahkan masalahnya yang kemudian mengarah kepada keputusan pembelian.Menurut Kotler \& Keller (2016:198), keputusan pembelian adalah "In the evaluation stage, the consumer forms preferences among the brands in the choice and may also from an intention to buy the most preferred brand".

Menurut Kotler dan Armstrong (2008:181), keputusan pembelian konsumen adalah membeli merek yang paling disukai dari berbagai alternatif yang ada, tetapi dua faktor bisa berada antara niat pembelian dan keputusan pembelian. Faktor pertama adalah sikap orang lain dan faktor yang kedua adalah faktor situasional. Oleh karena itu, preferensi dan niat pembelian tidak selalu menghasilkan pembelian yang aktual.

Menurut Kanuk (2009: 112), keputusan pembelian adalah pemilihan dari dua atau lebih alternatif pilihan keputusan pembelian, artinya bahwa seseorang dapat membuat keputusan, harus tersedia beberapa alternatif pilihan. Keputusan untuk membeli dapat mengarah pada bagaimana proses dalam pengambilan keputusan tersebut itu dilakukan. Keputusan pembelian konsumen dipengaruhi oleh perilaku konsumen.

Berdasarkan uraian diatas dapat disimpulkan bahwa keputusan pembelian adalah proses dimana seorang konsumen menentukan keputusannya dalam pembelian berdasarkan alternatif pilihan yang sesuai dengan kepentingankepentingan tertentu dengan menetapkan suatu pilihan yang dianggap paling menguntungkan.

B. Kualitas Produk

1) Pengertian Kualitas Produk

Kualitas produk merupakan pemahaman bahwa produk merupakan peluang ditawarkan oleh penjual mempunyai nilai jual lebih yang tidak dimiliki oleh produk pesaing. Oleh karena itu perusahaan berusaha memfokuskan pada kualitas produk dan membandingkannya dengan produk yang ditawarkan oleh perusahaan pesaing.

Menurut Kotler dan Amstrong (2012:283) Kualitas produk adalah kemampuan suatu produk untuk melaksanakan fungsinya, meliputi daya tahan, keandalan, ketepatan, kemudahan operasi dan perbaikan, serta atribut bernilai lainnya.

Menurut Purnama (2006:11), kualitas produk adalah kesesuaian antara kebutuhan dan keinginan atas produk ke dalam spesifikasi produk yang dihasilkan.Menurut Goetsch dan Davis (2002:4) bahwa "Kualitas produk adalah suatu kondisi dinamis yang berhubungan dengan barang, jasa, manusia, produk, dan lingkungan yang memenuhi atau melebihi harapan".

Kualitas sering dianggap sebagai ukuran relatif kebaikan suatu produk atau jasa yang terdiri atas kualitas desain dan 
kualitas kesesuaian. Kualitas desain merupakan fungsi spesifikasi produk, sedangkan kualitas kesesuaian adalah suatu ukuran seberapa jauh suatu produk mampu memenuhi persyaratan atau spesifikasi kualitas yang telah ditetapkan (Tjiptono,2006: 59).

\section{Harga}

1) Pengertian Harga

Dengan semakin banyaknya produsen yang terlibat dalam pemenuhan kebutuhan dan keinginan konsumen, menyebabkan setiap perusahaan harus dapat teliti dalam menetapkan harga. Menetapkan harga suatu produk tidaklah semudah yang kita bayangkan, ada beberapa proses yang harus dilakukan dalam penetapan harga suatu produk. Dalam menentukan harga terdapat strategi harga yang diartikan sebagai salah satu konten strategi pemasaran yang mengarah pada upaya pembentukan citra harga, daya saing harga, citra mutu, dan nilai pelanggan (Ferdinand, 2002).

Menurut Ferdinand (2000), harga merupakan salah satu variabel penting dalam pemasaran, dimana harga dapat mempengaruhi konsumen dalam mengambil keputusan untuk membeli suatu produk, karena berbagai alasan. Alasan ekonomis akan menunjukkan bahwa harga yang rendah atau harga yang selalu berkompetisi merupakan salah satu pemicu penting untuk meningkatkan kinerja pemasaran, tetapi alasan psikologis dapat menunjukkan bahwa harga justru merupakan indikator kualitas dan karena itu dirancang sebagai salah satu instrumen penjualan sekaligus sebagai instrumen kompetisi yang menentukan.

$$
\text { Craig S (2000, p.58) }
$$

mengidentifikasikan harga sebagai salah satu faktor penting yang berpengaruh terhadap perilaku konsumen dalam keputusan pembelian sehubungan dengan nilai dari produk atau jasa. Para konsumen tertarik untuk mendapatkan harga yang pantas. Harga yang pantas berarti nilai yang dipersepsikan pantas pada saat transaksi dilakukan. Konsumen beranggapan bahwa suatu produk dengan harga yang mahal berarti mempunyai kualitas yang baik.
Sedangkan apabila harga yang murah mempunyai kualitas yang kurang baik.

Pendapat Hermann et al (2007) menunjukkan bahwa harga menjadi salah satu faktor penting dalam pembelian pelanggan, sehingga memiliki dampak yang signifikan terhadap kepuasan pelanggan. Juga, kepuasan konsumen dipengaruhi oleh persepsi harga langsung dan dipengaruhi oleh keadilan harga secara tidak langsung. Penelitian lain, leeet al (2010) dalam mirabi et al (2015:269) menjelaskan bahwa efek dari persepsi konsumen keadilan harga pada pembelian keputusan dan disebut sebagai prediktor yang tepat untuk keputusan pembelian konsumen. Nilai yang baik diimbalan uang yang diterima antara kriteria konsumen yang didasarkan pada pertimbangan. Menurut Khraim (2011, seperti dikutip dalam Aker, 1991), harga memiliki dampak yang signifikan terhadap loyalitas merek yang menimbulkan minat beli pada pelanggan.

Dari definisi di atas dapat disimpulkan bahwa harga adalah suatu nilai tukar dari produk barang maupun jasa yang dinyatakan dalam satuan moneter, harga merupakan salah satu bagian yang sangat penting dalam pemasaran suatu produk karena harga adalah satu dari empat bauran pemasaran $/$ marketing mix $(4 \mathrm{P}=$ product, price, place, promotion / produk, harga, distribusi, promosi).

\section{Citra Merk}

1) Pengertian Citra Merk

Citra merek merupakan keseluruhan persepsi terhadap produk atau merek yang dibentuk dari informasi dan pengalaman masa lalu terhadap produk atau merek itu (Sutisna, 2003:83). Definisi lain citra merek adalah kesan yang diperoleh sesuai dengan pengetahuan dan pemahaman seseorang tentang sesuatu (Alma, 2004: 375). Citra terbentuk dari bagaimana perusahaan melaksanakan kegiatan operasionalnya yang mempunyai landasan utama pada segi layanan. Menurut Tandjung (2004:59), citra merek merupakan kumpulan asosiasi merek yang membentuk suatu persepsi tertentu terhadap merek tersebut. Sedangkan asosiasi merek adalah segala 
sesuatu yang terjalin di dalam ingatan sebuah merek.

Citra merek umumnya didefinisikan segala hal yang terkait dengan merek yang ada dibenak ingatan konsumen. Citra merek merepresentasikan keseluruhan persepsi konsumen terhadap merek yang terbentuk karena informasi dan pengalaman konsumen terhadap suatu merek (Suryani, 2008: 113).

E. Hubungan Kualitas Produk, Harga, dan Citra Merek Terhadap Keputusan Pembelian

Kualitas produk, harga, dan citra merek memiliki hubungan sebab akibat, harga sangat menentukan kualitas produk bila harga mahal maka kualitasnya lebih baik, Menurut Chandra dalam Tjiptono (2006:179) dikatakan bahwa harga merupakan pernyataan nilai dari suatu produk (a statement of value). Citra merek adalah kesan yang diperoleh sesuai dengan pengetahuan dan pemahaman seseorang mengenai sesuatu (Alma, 2004: 375). Citra merek memiliki hubungan yang baik dengan kualitas produk, kualitas produk yang bagus akan menciptakan citra merek yang begitu bagus.

Menurut Kotler dan Amstrong (2012:283) Kualitas produk adalah kemampuan suatu produk untuk melaksanakan fungsinya, meliputi daya tahan, keandalan, ketepatan, kemudahan operasi dan perbaikan, serta atribut bernilai lainnya. Kualitas produk, harga, dan citra merek dapat mempengaruhi keputusan pembelian konsumen melalui pengetahuan atau informasi yang didapat konsumen mengenai produk. Menurut Kotler dan Armstrong (2008:181), keputusan pembelian konsumen adalah membeli merek yang paling disukai dari berbagai alternatif yang ada, tetapi dua faktor bisa berada antara niat pembelian dan keputusan pembelian.

\section{F. Penelitian Terdahulu yang Relevan}

Penelitian ini berdasarkan penelitian terdahulu yaitu sebagai berikut:

1) Sugianto (2007), analisis pengaruh kualitas layanan, citra merek, harga, dan promosi terhadap keputusan pembelian kopi instan "indocafe". Penelitian ini merupakan jenis penelitian asosiatif, dimana dilakukan analisis regresi berganda untuk melihat pengaruh antara variabel bebas dan terikat. Hasil penelitian ini menunjukan bahwa kualitas layanan, citra merek, harga, dan promosi berpengaruh terhadap keputusan pembelian kopi instan "indocafe".Persamaan dengan penelitian ini terletak pada variabel keputusan pembelian sebagai variabel terikat dan untuk variabel bebasnya citra merek dan harga. Sedangkan untuk perbedaanya yaitu beberapa variabel bebasnya dan objek yang diteliti.

2) Dinawan (2010), analisis faktor yang mempengaruhi keputusan pembelian (studi kasus pada konsumen yamaha mio pt harpindo jaya Semarang. Dalam penelitian ini yang menjadi varial bebas antara lain kualitas produk, harga kompetitif, dan citra merek. Sedangkan untuk variabel terikat yaitu keputusan pembelian. Untuk variabel yang paling mempengaruhi keputusan pembelian yaitu variabel citra merek. Persamaan dengan penelitian ini terletak pada variabel terikat keputusan pembelian dan variabel bebas kualitas produk dan citra merek. Sedangkan perbedaannya yaitu terletak pada beberapa variabel bebas dan objek yang diteliti.

3) Saputra (2013) analisis pengaruh strategi pemasaran terhadap keputusan pembelian teh celup sariwangi oleh rumah tangga dikota Medan. Berdasarkan penelitian ini variabel kualitas produk, harga, saluran distribusi, dan promosi berpengaruh terhadap keputusan pembelian. Persamaan penelitian ini pada variabel terikat yaitu keputusan pembelian dan variabel bebas yaitu kualitas produk dan harga. Sedangkan perbedaannya pada variabel bebas dan obyek penelitian.

\section{HIPOTESIS}

Hipotesis adalah hubungan yang diperkirakan secara logis di antara dua atau lebih variabel yang diungkapkan dalam bentuk pernyataan yang dapat diuji. Hubungan 
tersebut diperkirakan berdasarkan jaringan asosiasi yang ditetapkan dalam kerangka teoritis yang dirumuskan untuk studi penelitian. Dengan menguji hipotesis akan menegaskan perkiraan hubungan, diharapkan bahwa solusi dapat ditemukan untuk mengatasi masalah yang dihadapi (Sekaran,2006: 135). Sedangkan hipotesis dalam penelitian ini adalah:

1. Diduga kualitas produk, harga, dan citra merek berpengaruh signifikan terhadap keputusan pembelian produk Madlyson di Aztekline Tulungagung.

2. Diduga kualitas produk berpengaruh dominan terhadap keputusan pembelian produk Madlyson di Aztekline Tulungagung.

\section{METODE PENELITIAN}

\section{A. Rancangan Penelitian}

Penelitian ini menggunakan pendekatan kuantiatif dengan metode penelitian survei, yaitu penelitian yang mengambil sampel dari suatu populasi serta menggunakan kuisoner sebagai alat pengumpul data yang utama. Berdasarkan tujuan penelitian yang telah ditetapkan, maka jenis penelitian ini adalah explanatory research, yaitu jenis penelitian yang berusaha menjelaskan hubungan antara variabel-variabel penelitian yang menguji hipotesis yang telah dirumuskan sebelumnya. Walaupun uraian-uraiannya mengandung deskripsi, namun sebagai penelitian relasional fokusnya terletak pada penjelasan hubungan antar variabel (Sofian, 2006). Dalam penelitian ini, yang menjadi objek adalah produk Madlyson di Aztekline Tulungagung.

\section{B. Ruang Lingkup Penelitian}

Penelitian ini berfokus pada pengamatan pengaruh kualitas produk, harga, dan citra merek terhadap keputusan pembelian produk Madlyson di AzteklineTulungagung. Dengan demikian, penelitian ini pada lingkup kajian produk Madlyson di Aztekline Tulungagung.

\section{Variabel Penelitian}

Klasifikasi Variabel

Variabel dalam penelitian ini diklasifikasikan menjadi dua variabel, yaitu variabel bebas dan variabel terikat. Variabel bebas terdiri atas kualitas produk
(X1), harga (X2), citra merek (X3). Variabel terikat dalam penelitian ini yaitu, keputusan pembelian produk madlyson di Aztekline (Y).

\section{Definisi Konseptual Variabel}

1) Kualitas produk

Kualitas produk adalah kesesuaian antara kebutuhan dan keinginan atas produk ke dalam spesifikasi produk yang dihasilkan (Purnama 2006:11).

2) Harga

Harga yaitu suatu atribut yang melekat pada suatu barang yang memungkinkan barang tersebut dapat memenuhi kebutuhan, keinginan, dan memuaskan konsumen yang dinyatakan dengan uang (Alma, 2004:169)

3) Citra merek

Citra merek merupakan keseluruhan persepsi terhadap produk atau merek yang dibentuk dari informasi dan pengalaman masa lalu terhadap produk atau merek itu (Sutisna, 2003:83).

4) Keputusan pembelian

Keputusan pembelian konsumen adalah membeli merek yang paling disukai dari berbagai alternatif yang ada (Kotler dan Armstrong 2008:181).

\section{E. Populasi dan Teknik Pengambilan} Sampel

1) Populasi

Populasi adalah gabungan dari sebuah elemen yang berbentuk peristiwa, hal, atau orang yang memiliki karakteristik yang serupa yang menjadi pusat perhatian seorang peneliti karena itu dipandang sebagai sebuah semesta penelitian (Ferdinand, 2006).

Dalam penelitian ini yang menjadi populasi adalah konsumen yang berkunjung dan membeli produk di Aztekline, sedangkan untuk rata-rata pengunjung yang membeli produk dalam satu bulan sebanyak 150 orang.

Tabel 3.3

Penjualan Produk di Aztekline

\begin{tabular}{|c|c|c|}
\hline No & Bulan & Jumlah Item Terjual \\
\hline 1 & Desember & 193 \\
\hline 2 & Januari & 179 \\
\hline 2 & Februari & 142 \\
\hline 3 & Maret & 129 \\
\hline
\end{tabular}




\begin{tabular}{|c|c|c|}
4 & April & 142 \\
\hline \multicolumn{2}{|c|}{ Sumber : Penjualan produk di aztekline }
\end{tabular}
bulan Desember2016 - April 2017

2) Sampel

Sampel adalah bagian dari jumlah dan karakteristik yang dimiliki oleh populasi. Jika populasi besar dan peneliti tidak mungkin mempelajari semua yang ada pada populasi, misalnya karena keterbatasan dana, waktu dan tenaga maka peneliti dapat menggunakan sampel yang diambil dari populasi tersebut. Apa yang dipelajari sampel, kesimpulannya akan dapat diberlakukan untuk populasi (Sugiyono, 2013:62).

Teknik pengambilan sampel pada penelitian ini adalah Insidental Sampling atau Aksidental. Teknik ini dilakukan dengan cara memilih sampel secara kebetulan ditemui saja. Proses pengambilan sampel dengan mengelompokkan konsumen yang akan di teliti. Pengambilan sampel berlangsung dalam 1 bulan. Pada teknik sampling ini digunakan untuk menjaring pendapat konsumen terhadap subyek tertentu, dengan demikian orang yang tidak membeli produk di tempat peneliti mengambil data tidak mendapat kesempatan untuk diteliti meskipun mereka menggunakan produk yang sama (Endang Mulyatiningsih, 2012:12).

Penentuan jumlah sampel (responden) ini menggunakan rumus dari Taro Yamane (dalam Riduwan dan Kuncoro, 2007:44) yaitu sebagai berikut:

Keterangan:

$$
\mathrm{n}=\frac{N}{N \times d^{2}+1}
$$

$\mathrm{n}=$ Jumlah Sampel

$\mathrm{N}=$ Jumlah Populasi (pengunjung dalam 1 bulan).

$\mathrm{d}^{2}=$ presisi (ditetapkan $10 \%$ ).

Berdasarkan rumus tersebut diperoleh jumlah minimal sampel pengunjung yang datang dalam 1 bulan sebagai berikut:

$$
\begin{gathered}
\mathrm{n}=\frac{150}{150 \times(0,1)^{2}+1} \\
\mathrm{n}=60
\end{gathered}
$$

Jadi jumlah minimal sampel pengunjung yang dibutuhkan dalam penelitian ini adalah sebanyak 60 responden yaitu konsumen yang datang dan pernah membeli produk madlyson di aztekline Tulungagung.

\section{F. Teknik Pengumpulan Data}

Untuk mendapatkan informasi yang valid maka diperlukan suatu teknik pengumpulan data yang tepat. Arikunto (2006:232) mengatakan bahwa mengumpulkan data adalah mengamati variabel yang akan diteliti dengan metode observasi, angket dan dokumentasi.

Pengumpulan data dalam penelitian ini menggunakan metode:

1. Observasi

Metode observasi dilakukan dengan cara peneliti langsung ke lapangan untuk mengamati dan mengumpulkan data. Observasi ini dilakukan untuk memperoleh informasi lokasi.

2. Kuesioner

Teknik pengumpulan data dengan memberikan daftar pertanyaan yang diajukan kepada responden yang dalam hal ini adalah pembeli di produk madlyson di aztekline Tulungagung.

3. Dokumentasi

Teknik pengumpulan data ini digunakan untuk memperoleh data tentang produk yang di pasarkan dan pengambilan gambar dilokasi penelitian.

\section{G. Teknik Analisis Data}

Teknik analisis data adalah rancangan unntuk menganalisis data yang telah dikumpulkan dari sumbersumbernya, baik pengamatan dilapangan atau dari sumber-sumber lainnya yang dapat disimpulkan dan diinformasikan kepada pihak. Kegiatan dalam menganalisis data adalah mengelompokkan data berdasarkan variabel dan jenis responden, mentabulasi data berdasarkan variable dari seluruh responden, menyajikan data dari setiap variabel yang diteliti, melakukan perhitungan untuk menjawab rumusan masalah dan melakukan penghitungan untuk menguji hipotesis yang telah diajukan (Sugiyono, 2012: 206).

Dalam penelitian ini analisis data yang digunakan adalah statistik deskriptif. Menurut Sugiyono (2012: 206), "statistik deskriptif adalah statistik yang digunakan 
untuk menganalisis data dengan cara mendeskripsikan atau menggambarkan data yang telah terkumpul sebagaimana adanya tanpa bermaksud membuat kesimpulan yang berlaku untuk umum atau generalisasi".

Data kuantitatif diperoleh dari hasil pengisian kuisioner oleh responden yang bersangkutan dengan masalah yang diteliti. Pengisian kuisioner dilakukan secara langsung oleh responden dengan memberi tanda pada jawaban yang telah disediakan. Alat ukur yang digunakan untuk mengumpulkan data dalam penelitian ini adalah skala likert dengan menggunakan variabel berukuran ordinal.

Setelah data diperoleh dengan lengkap sesuai dengan yang dibutuhkan, selanjutnya dilakukan proses analis data sebagai berikut:

\section{Uji Validitas}

Uji validitas digunakan untuk mengukur sah atau valid tidaknya suatu kuisioner. Suatu kuisoner dikatakan valid jika pertanyaan dalam kuisioner mampu mengungkapkan sesuatu yang akan diukur oleh kuisioner tersebut (Imam ghozali, 2011: 52). Uji validitas dalam penelitian ini menggunakan korelasi product moment, yaitu dengan rumus:

$$
r x y=\frac{\mathrm{N}\left(\sum \mathrm{xy}\right)-\left(\sum \mathrm{x}\right)\left(\sum \mathrm{y}\right)}{\sqrt{\left\{N \sum x^{2}-\left(\sum x\right)^{2}\right\}\left\{N \sum y^{2}-\left(\sum y\right)^{2}\right\}}}
$$

Keterangan

$\mathrm{r}_{\mathrm{xy}}=$ koefisien korelasi antar variabel $\mathrm{X}$ dan variabel $\mathrm{Y}$

$\mathrm{N} \quad=$ jumlah responden

$\sum X Y=$ jumlah hasil kali skor $\mathrm{X}$ kali $\mathrm{Y}$

$\sum X=$ jumlah skor $X$

$\sum \mathrm{Y}=$ jumlah skor $\mathrm{Y}$

$\left(\sum X\right)^{2}=$ kuadrat jumlah skor $\mathrm{X}$

$\left(\sum \mathrm{Y}\right)^{2}=$ kuadrat jumlah skor $\mathrm{Y}$

Pengujian dilakukan dengan cara mengkorelasikan antar skor item setiap butir pertanyaan dengan skor total, selanjutnya interprestasi dari koefisien korelasi yang dihasilkan, koefisien korelasi yang dihasilkan kemudian dibandingkan dengan $r_{\text {tabel }}$ apabila $r_{\text {hitung }}>$ $r_{\text {tabel }}$ maka dinyatakan valid.

2. Uji Reliabilitas

Reliabilitas dalah seberapa jauh kosistensi alat ukur dapat memberikan hasil yang sama dalam mengukur hal dan subjek yang sama (Iqbal Hasan, 2008: 15). Reliabilitas adalah istilah yang dipakai untuk menunjukkan seberapa besar hasil pengukuran relatif konsisten apabila pengukuran diulang lebih dari sekali.

Menurut Arikunto (2002:193) reliabilitas dihitung dengan rumus sebagai berikut :

$$
r=\frac{\mathrm{k}}{\mathrm{k}-1}\left(1-\frac{\sum \partial^{2} \mathrm{a}}{\partial^{2} \mathrm{~b}}\right)
$$

$$
\begin{aligned}
& \text { Keterangan: } \\
& \mathrm{r} \quad=\text { Reliabilitas instrument } \\
& \mathrm{k} \quad \text { = Banyaknya butir pertanyaan } \\
& \partial^{2} \mathrm{a} \quad \text { Jumlah Varians butir } \\
& \partial^{2} \mathrm{~b} \quad=\text { Varians total }
\end{aligned}
$$

Menurut Imam Ghozali (2011), nilai koefisien reliabilitas yang baik diatas 0,7. Pengukuran validitas dan realibilitas mutlak dilakukan, karena jika instrument yang digunakan sudah tidak valid dan reliable maka dipastikan hasil penelitiannya pun tidak valid dan reliable (Sugiyono, 2012).

3. Uji Asumsi Klasik

Model regresi linier berganda dapat disebut sebagai model yang baik jika telah memenuhi kriteria BLUE (Best Linear Unibased Estimator). BLUE dapat dicapai apabila memenuhi uji asumsi klasik. Asumsi klasik dalam penelitian ini adalah uji normalitas, uji multikolinearitas, dan uji heteroskedastisitas.

a. Uji Normalitas

Menurut Imam Ghozali (2011, 160), uji normalitas bertujuan untuk menguji apakah dalam model regresi, variabel pengganggu atau residual memiliki distribusi normal, bila asumsi ini dilanggar maka uji statistik menjadi tidak valid untuk jumlah sampel kecil. Uji normalitas data dilakukan dengan uji Kolmogorov smirnov. Untuk mempermudah dalam melakukan perhitungan secara statistik. Data dinyatakan berdistribusi normal apabila nilai asymp sig (2-tailed) lebih besar dari $1 / 2 \alpha$.

b. Uji Multikolinieritas 
Menurut Imam Ghozali (2011: 105), uji multikolinieritas bertujuan untuk menguji apakah model regresi ditemukan adanya korelasi antar variabel bebas. Model regresi yang baik seharusnya tidak terjadi korelasi diantara variabel bebas. Untuk mendeteksi ada tidaknya multikolinieritas didalam model regresi pada penelitian ini menggunakan besaran VIF (variance inflation factor) dan tolerance, untuk mendeteksi multikolinieritas sebagai berikut:

Besaran VIF (variance inflation factor) dan tolerance

- Mempunyai nilai VIF +/- 1

- Mempunyai angka tolerance $+/-1$

- Atau tolerance $=1 / \mathrm{VIF}$ dan $\mathrm{VIF}=1 /$ tolerance

- Nilai cut off yang umumnya dipakai untuk menunjukkan adanya multikolinieritas adalah nilai VIF > 5 dipastikan terjadi multikolinieritas.

c. Uji Heteroskedastisitas

Menurut Imam Ghozali (2011, 193), uji heteroskedastitas bertujuan menguji apakah model regresi terjadi ketidaksamaan variance dari residual satu pengamatan ke pengamatan lain. Jika variance dari residual satu pengamatan ke pengamatan lain tetap. Maka disebut homoskedastitas dan jika berbeda disebut heteroskedastitas.

4. Analisis Regresi Berganda

Analisis data dilakukan dengan menggunakan teknik analisis regresi berganda. Regresi linier berganda adalah regresi dimana variabel terikat $(\mathrm{Y})$ dihubungkan atau dijelaskan lebih dari satu variabel, mungkin satu, dua, tiga, dan seterusnya variabel bebas $(\mathrm{X} 1, \mathrm{X} 2, \mathrm{X} 3, \ldots \mathrm{Xn})$ namun masih menunjukkan diagram hubungan yang linier (Iqbal Hasan, 2008). Sebelum model regresi digunakan untuk menguji hipotesis, maka terlebih dahulu dilakukan pengujian asumsi klasik. Regresi berganda berguna untuk mendapatkan pengaruh dua variabel kriterium atau untuk mencari hubungan fungsional dua variabel predictor atau lebih dengan variabel kriteriumnya, atau untuk meramalkan dua variabel predictor atau lebih terhadap variabel kriteriumnya (Susanti, 2010:185).
Rumus analisis regresi linier berganda akan disajikan dengan model rumus berikut:

Keterangan

$$
\mathrm{Y}=\mathrm{a}+\mathrm{b}_{1} \mathrm{x}_{1}+\mathrm{b}_{2} \mathrm{x}_{2}+\mathrm{b}_{3} \mathrm{x}_{3}
$$

$\begin{array}{ll}\mathrm{Y} & =\text { keputusan pembelian } \\ \mathrm{a} & =\text { konstanta } \\ \mathrm{b} & =\text { koefisien regresi } \\ \mathrm{x} 1 & =\text { kualitas produk } \\ \mathrm{x} 2 & =\text { harga } \\ \mathrm{x} 3 & =\text { citra merek }\end{array}$

\section{Uji Hipotesis}

a. Uji F

Uji $F$ ini digunakan untuk mngetahui besarnya variabel bebas secara bersama-sama terhadap variabel terikat. Untuk mengetahui regresi tersebut signifikan atau tidak, digunakan rumus sebagai berikut (Rangkuti 2003:165)

Keterangan

$$
F=\frac{\mathrm{R}^{2} / \mathrm{k}}{(1-R) /(n-k-i)}
$$

$\mathrm{F}=$ pendekatan distribusi probabilitas

$\mathrm{K}=$ jumlah variabel indepenen

$\mathrm{R}^{2}=$ koefisien determinasi

$\mathrm{n}=$ banyaknya sampel

\section{Kriteria}

1) Jika $F$ hitung $>$ dari $F$ tabel maka $H_{0}$ ditolak dan $\mathrm{H}_{\mathrm{a}}$ diterima yang berarti ada pengaruh.

2) Jika $F$ hitung < dari $F$ tabel maka $H_{o}$ diterima dan $\mathrm{H}_{\mathrm{a}}$ ditolak yang berarti tidak ada pengaruh.

b. Uji t

Untuk mengetahui pengaruh kualitas produk, harga, dan citra merek secara parsial terhadap keputusan pembelian, digunakan uji t. Menurut Rangkuti (2003:166) rumusnya adalah :

Keterangan :

$$
T b=\frac{\mathrm{b}}{\mathrm{Sb}}
$$

$\mathrm{Tb}=$ besarnya $\mathrm{t}$ hitung

$\mathrm{B}=$ parameter estimasi

$\mathrm{Sb}=$ standar eror

\section{Kriteria}

1) Jika t hitung > dari t tabel maka $\mathrm{H}_{\mathrm{o}}$ ditolak dan $\mathrm{H}_{\mathrm{a}}$ diterima yang berarti ada pengaruh. 
2) Jika t hitung < dari t tabel maka $\mathrm{H}_{\mathrm{o}}$ diterima dan $\mathrm{H}_{\mathrm{a}}$ ditolak yang berarti tidak ada pengaruh.

\section{HASIL PENELITIAN}

\section{Deskripsi Responden}

a. Berdasarkan Jenis Kelamin

Karakteristik responden berdasarkan jenis kelamin tersaji sebagaimana tabel berikut:

Tabel 4.1

Karakteristik Responden

Berdasarkan Jenis Kelamin

\begin{tabular}{|l|l|l|l|}
\hline No. & $\begin{array}{l}\text { Jenis } \\
\text { Kelamin }\end{array}$ & Jumlah & $\begin{array}{l}\text { Prose } \\
\text { ntase }\end{array}$ \\
\hline 1. & Laki-Laki & 42 & $70 \%$ \\
\hline 2. & Perempuan & 18 & $30 \%$ \\
\hline & Total & 60 & $\begin{array}{l}100 \\
\%\end{array}$ \\
\hline
\end{tabular}

Sumber data: data primer, 2017

Data tabel 4.1 diketahui deskripsi responden berdasarkan jenis kelamin, jenis kelamin laki-laki sebanyak 42 responden (70\%) dan jenis kelamin perempuan sebanyak 18 responden (30\%). Dengan demikian dapat disimpulkan bahwa responden terbanyak yaitu jenis kelamin laki-laki.

b. Berdasarkan Usia

Karakteristik responden berdasarkan usia tersaji sebagaimanatabel berikut:

Tabel 4.2

Karakteristik Responden Berdasarkan Usia

\begin{tabular}{|l|l|l|l|}
\hline No. & Usia & Jumlah & $\begin{array}{l}\text { Prosentas } \\
\mathrm{e}\end{array}$ \\
\hline 1 & $<15$ tahun & 3 & $5 \%$ \\
\hline 2 & $16-20$ tahun & 19 & $31,7 \%$ \\
\hline 3 & $21-25$ tahun & 21 & $35 \%$ \\
\hline 4 & $26-30$ tahun & 11 & $18,3 \%$ \\
\hline 5 & $>30$ tahun & 6 & $10 \%$ \\
\hline & Total & 60 & $100 \%$ \\
\hline
\end{tabular}

Sumber data: data primer, 2017

Data tabel 4.2 diketahui deskripsi responden berdasarkan usia, usia $<15$ tahun sebanyak 3 responden (5\%), 16-20 tahun sebanyak 19 responden (31,7\%), 21-25 tahun sebanyak 21 responden (35\%), 26-30 tahun sebanyak 11 responden $(18,3 \%),>30$ tahun sebanyak 6 responden (10\%). Dengan demikian dapat disimpulkan bahwa responden terbanyak pada usia 31-25 tahun.

c. Berdasarkan Pekerjaan
Karakteristik presponden berdasarkan pekerjaan tersaji sebagaiman pada tabel berikut:

Tabel 4.3

Karakteristik Responden Berdasarkan Pekerjaan

\begin{tabular}{|l|l|l|l|}
\hline No. & Pekerjaan & Jumlah & Presentase \\
\hline 1 & $\begin{array}{l}\text { PNS/ } \\
\text { BUMN }\end{array}$ & 2 & $3,3 \%$ \\
\hline 2 & $\begin{array}{l}\text { Pegawai } \\
\text { Swasta }\end{array}$ & 16 & $26,7 \%$ \\
\hline 3 & $\begin{array}{l}\text { Ibu rumah } \\
\text { tangga }\end{array}$ & 1 & $1,7 \%$ \\
\hline 4 & $\begin{array}{l}\text { Pelajar/ } \\
\text { Mahasiswa }\end{array}$ & 35 & $58,3 \%$ \\
\hline 5 & Wiraswasta & 6 & $10 \%$ \\
\hline & Total & 60 & $100 \%$ \\
\hline
\end{tabular}

Sumber data: Data primer diolah, 2017

Data tabel 5 dapat diketahui deskripsi responden berdasarkan pekerjaan, PNS/ BUMN sebanyak 2 responden (3,3\%). Pegawai swasta sebanyak 16 responden $(26,7 \%)$, ibu rumah tangga sebanyak 1 responden $(1,7 \%)$, pelajar / mahasiswa sebanyak 35 responden $(58,3 \%)$, dan wiraswasta sebanyak 6 responden (10\%). Dengan demikian terbanyak responden adalah pelajar/ mahasiswa.

\section{Hasil Analisis Regresi Berganda}

Analisis regresi berganda digunakan untuk mengetahui besarnya pengaruh dari variabel kualitas produk, harga, dan citra merek terhadap keputusan pembelianproduk. Hasil perhitungan dengan menggunakan SPSS versi 16 for windows disajikan pada tabel berikut:

Tabel 4.14

Rekapitulasi Hasil Analisis Regresi Linier Berganda

\begin{tabular}{|c|l|c|}
\hline $\begin{array}{c}\text { Variab } \\
\text { el }\end{array}$ & \multicolumn{1}{|c|}{ Keterangan } & $\begin{array}{c}\text { Koefisien } \\
\text { Regresi }\end{array}$ \\
\hline $\mathrm{X}_{1}$ & Kualitas Produk & 0,160 \\
$\mathrm{X}_{2}$ & Harga & 0,128 \\
$\mathrm{X}_{3}$ & Citra Merek & 0,568 \\
\hline
\end{tabular}

\begin{tabular}{l|r} 
Konstanta & 9,932 \\
$\mathrm{R}$ & 0,681 \\
$\mathrm{R}$ square & 0,463 \\
$\mathrm{n}$ & 60 \\
\hline
\end{tabular}

Variabel terikat $=$ Keputusan Pemblian $(\mathrm{Y})$ Sumber data: Data primer diolah SPSS, 2017

Hasil perhitungan regresi berganda tersebut dapat diketahui formulasinya sebagai berikut:

$\mathrm{Y}=\mathrm{a}+\mathrm{b}_{1} \mathrm{X}_{1}+\mathrm{b}_{2} \mathrm{X}_{2}+\mathrm{b}_{3} \mathrm{X}_{3}+\mathrm{e}$ 
$Y=9.932+0,160 X_{1}+0,128 X_{2}+0,568 X_{3}+$

e

Berdasarkan hasil persamaan tersebut, maka dapat dijelaskan sebagai berikut :

a. Konstanta (a) = 9.932 dapat diartikan bahwa rata-rata kontribusi variabel lain diluar model masih berpengaruh terhadap keputusan pembelian produk.

b. Koefisien regresi kualitas produk sebesar 0,160 , menunjukkan besarnya pengaruh kualitas produk terhadap keputusan pembelian produk, jika $\mathrm{X}_{1}$ berubah 1 satuan, maka y akan berubah sebesar 0,160 .

c. Koefisien regresi harga sebesar 0,128, menunjukkan besarnya pengaruh harga terhadap keputusan pembelian produk, jika $\mathrm{X}_{2}$ berubah 1 satuan, maka y akan berubah sebesar 0,128.

d. Koefisien regresi citra merek sebesar 0,568 , menunjukkan besarnya pengaruh citra merek terhadap keputusan pembelian produk, jika $\mathrm{X}_{3}$ berubah 1 satuan, maka y akan berubah sebesar 0,568.

e. Koefisien korelasi berganda (R) sebesar 0,681 ; menunjukkan bahwa secara bersama-sama memiliki hubungan yang kuat dan searah antara kualitas produk, harga, dan citra merek terhadap keputusan pembelian produk. Hubungan ini dapat dikategorikan sangat kuat, sebagaimana diketahui bahwa suatu hubungan dikatakan sempurna jika koefisien korelasinya mencapai angka 100\% atau 1 (baik dengan angka positif atau negatif).

Hasil analisis regresi linier berganda di atas, dapat diketahui nilai koefisien determinasi ( $R$ square) sebesar 0,463. Angka ini menunjukkan bahwa variabel kualitas produk, harga, dan citra merekmampu memberikan kontribusi terhadap variabel terikat (keputusan pembelian) sebesar 46,3\%, sedangkan sisanya sebesar $53,7 \%$ disebabkan oleh kontribusi di luar variabel penelitian.

\section{Pengujian Hipotesis}

Hipotesis 1. Kualitas produk, harga dan citra merek berpengaruh positif dan signifikan terhadap keputusan pembelian untuk menguji apakah seluruh variable-variabel bebas secara bersama-sama atau simultan, yaitu kualitas produk, harga dan citra merek berpengaruh positif dan signifikan terhadap keputusan pembelian, dengan cara membandingkan antara $\mathrm{F}_{\text {hitung }}$ dengan $\mathrm{F}_{\text {tabel }}$.
Hasil pengujian hipotesis dengan menggunakan uji $F$ menunjukkan bahwa terdapat pengaruh dari kualitas produk, harga dan citra merek berpengaruh positif dan signifikan terhadap keputusan pembelian. Hal ini terbukti dari hasil analisis yang memperoleh nilai $F_{\text {hitung }}>F_{\text {tabel }}$ $(16,110>2,76)$ dan nilai signifikan lebih kecil dari $\alpha=0,05(0,000<0,05)$. Artinya keputusan pembelian dapat dipengaruhi oleh kualitas produk, harga dan citra merek yang dilakukan oleh Aztekline Tulungagung. Semakin baik kualitas produk, harga dan citra merek, maka semakin tinggi keputusan pembelian di Aztekline Tulungagung.

Hipotesis 2. Kulialitas produk berpengaruh dominan terhadap keputusan pembelian konsumen dengan cara membandingkan antara $t_{\text {hitung }}$ dengan $\mathrm{t}_{\text {tabel }}$ Rumusan hipotesis :

Ho : bi $=0$ Kualitas produk tidak berpengaruh dominan terhadap keputusan pembelian konsumen

Ha : bi $\neq 0$ Kualitas produk berpengaruh dominan terhadap keputusan pembelian konsumen

Kriteria pengujian :

$\alpha=0,05(5 \%)$,

Derajat kebebasan $(\mathrm{dk})=\mathrm{n}-\mathrm{k}=60-4=56$

Diperoleh nilai $t_{\text {tabel }}=2,003$

Ho ditolak jika $t_{\text {hitung }} \geq t_{\text {tabel }}$ atau signifikan $t \leq$ 0,05

Ho diterima jika $t_{\text {hitung }} \leq t_{\text {tabel }}$ atau signifikan $t \geq$ 0,05

Hasil perhitungan $t_{\text {hitung }}$ dan $t_{\text {tabel }}$ masingmasing variabel bebas adalah sebagai berikut:

Tabel 4.15

Uji t

Perbandingan $\mathrm{t}_{\text {hitung }}$ dan $\mathrm{t}_{\text {tabel }} \alpha=5 \%$

\begin{tabular}{|c|c|c|c|c|}
\hline Variabel & $t_{\text {hitung }}$ & $t_{\text {tabel }}$ & Sig. & Keterangan \\
\hline $\begin{array}{c}\text { Kualitas } \\
\text { Produk }\end{array}$ & 2,167 & 2,003 & 0,035 & Signifikan \\
\hline Harga & 2,224 & 2,003 & 0,030 & Signifikan \\
\hline $\begin{array}{c}\text { Citra } \\
\text { Merek }\end{array}$ & 4,268 & 2,003 & 0,000 & Signifikan \\
\hline
\end{tabular}

Sumber data: Data primer diolah SPSS, 2017

Berdasarkan Tabel 4.15, t hitung dari masing-masing variabel bebas terhadap variabel terikat merupakan kombinasi baris $\mathrm{t}$ dan kolomXI, X2 dan kolom X3 (sesuai urutan variabel). Nilai t hitung dari X1 terhadap $\mathrm{Y}$ senilai 2.167, X2 terhadap Y senilai 2.224 dan 
dari X3 terhadap Y senilai 4.268. Selanjutnya, menurut Partino dan Idrus (2010: 58), t tabel dilihat dari DegreeofFreedom atau df yang diperoleh melalui perhitungan $\mathrm{df}=\mathrm{N}-\mathrm{k}$, dengan $\mathrm{N}$ merupakan jumlah sampel dan k merupakan jumlah variabel. Berdasarkan jumlahh sampel dalam penelitian ini sejumlah 60 dan jumlah variabel dalam penelitian ini yakni 4, maka perhitungan $t$ tabel dalam penelitian ini sebagai berikut:

$$
\begin{aligned}
& \mathrm{df}=60-4 \\
& \mathrm{df}=56
\end{aligned}
$$

t tabel pada $\mathrm{df}=56$ menunjukkan nilai 2.003. Selanjutnya, nilai t hitung dari setiap variabel bebas terhadap variabel terikat dianalisis dengan cara dibandingkan dengan nilai $\mathrm{t}$ tabel. Sehingga, dapat disimpulkan bahwa:

a) Pengaruh dari kualitas produk (X1) terhadap keputusan pembelian (Y) sebagai berikut :

Nilai t hitung (2.167) $>\mathrm{t}$ tabel (2.003) serta tingkat signifikansi $0.035<0.05$. Dengan demikian Ho ditolak dan $\mathrm{Ha}$ diterima. Sehingga, dapat disimpulkan bahwa ada pengaruh yang signifikan dari kualitas produk terhadap keputusan pembelian produkmadlyson di aztekline tulungagung.

b) Pengaruh dari harga (X2) terhadap keputusan pembelian produk madlyson di aztekline tulungagung, yakni sebagai berikut :

Nilai $\mathrm{t}$ hitung $(2.224)>\mathrm{t}$ tabel $(2.003)$ serta tingkat signifikansi $0.000<0.05$. Dengan demikian Ho ditolak dan $\mathrm{Ha}$ diterima. Sehingga, dapat disimpulkan bahwa ada pengaruh yang signifikan dari harga terhadap keputusan pembelian produk madlyson di aztekline tulungagung.

c) Pengaruh dari citra merek (X3) terhadap keputusan pembelian produk madlyson di aztekline tulungagung, yakni sebagai berikut :

Nilai t hitung (4.628) > t tabel (2.003) serta tingkat signifikansi $0.000<0.05$. Dengan demikian Ho ditolak dan $\mathrm{Ha}$ diterima. Sehingga, dapat disimpulkan bahwa ada pengaruh yang signifikan dari citra merek terhadap keputusan pembelian produk madlyson di aztekline tulungagung.
Berdasarkan hasil analisis regresi linier berganda pada 66 tati 4.14, maka dapat dibuktikan bahwa koefisien kualitas produk $=0,160$, harga $=0,128$, dan citra merek $=0,568$, Dengan demikian citra merek berpengaruh dominan terhadap keputusan pembelian. Dengan demikian hipotesis kedua yang menyatakan bahwa kualitas produk berpengaruh dominan terhadap keputusan pembelian konsumen di Aztekline Tulungagung, secara 66tatistic tidak diterima atau tidak teruji.

\section{PEMBAHASAN}

\section{A. Pengaruh Kualitas Produk Terhadap Keputusan Pembelian}

Hasil penelitian menunjukkan pengaruh kualitas produk terhadap keputusan pembelian produk madlyson di aztekline Tulungagung. Kualitas yang bagus seperti bahan yang digunakan serta model desain yang lebih berkualitas akan memotivasi konsumen untuk menentukan keputusannya dalam membeli. Hasil penelitian ini mendukung teori Kotler (2002) yang menyatakan bahwa keputusan pembelian adalah tindakan konsumen untuk mau membeli atau tidak terhadap produk. Dari berbagai faktor yang mempengaruhi konsumen dalam melakukan pembelian suatu produk, biasanya konsumen selalu mempertimbangkan kualitas, harga, dan produk yang sudah dikenal oleh masyarakat. Hasil penelitian ini juga mendukung penelitian terdahulu yang telah dilakukan oleh Saputra (2013), yang menyatakan bahwa variabel kualitas produk berpengaruh terhadap keputusan pembelian.

\section{B. Pengaruh Harga Terhadap Keputusan Pembelian}

Hasil pengujian hipotesis membuktikan bahwa variabel hargamemiliki pengaruh terhadap keputusan pembelian produk madlyson di aztekline tulungagung. Secara statistik membuktikan bahwa harga berpengaruh terhadap variabel keputusan pembelian.

Faktor harga produk selalu menjadi faktor penting dalam proses setiap pembelian pelanggan atau konsumen. Konsumen selalu memeriksa informasi harga dan nama merek berbeda ketika mereka membuat penilaian pada ukuran kualitas: kemudahan penggunaan, kegunaan, kinerja, ketahanan, dan status (Naylor, 2012: 487).Hasil penelitian ini dinilai 
memiliki persamaan dengan hasil penelitian yang telah dilakukan oleh Sugianto (2007) yang menyatakan bahwa kualitas layanan, citra merek, harga, dan promosi berpengaruh terhadap keputusan pembelian.

\section{Pengaruh Citra merek Terhadap Keputusan Pembelian}

Hasil pengujian hipotesis membuktikan bahwa variabel citra merek memiliki pengaruh paling dominan terhadap keputusan pembelian produk madlyson di aztekline tulungagung dibandingkan variabel lainnya. Hasil penelitian ini mendukung teori Alma (2004) yang menyatakan bahwa citra merek adalah kesan yang diperoleh sesuai dengan pengetahuan dan pemahaman seseorang mengenai sesuatu. Citra merek memiliki hubungan yang baik dengan kualitas produk, kualitas produk yang bagus akan menciptakan citra merek yang begitu bagus.

Hasil penelitian ini dinilai memiliki persamaan dengan hasil penelitian yang telah dilakukan oleh Dinawan (2010) yang menyatakan bahwa faktor yang mempengaruhi keputusan pembelian (studi kasus pada konsumen yamaha mio pt harpindo jaya Semarang). Dalam penelitian ini yang menjadi variabel bebas antara lain kualitas produk, harga kompetitif, dan citra merek. Sedangkan untuk variabel terikat yaitu keputusan pembelian. Untuk variabel yang paling mempengaruhi keputusan pembelian yaitu variabel citra merek.

\section{KESIMPULAN}

Berdasarkan latar belakang, tujuan penelitian, hasil analisis dan pembahasan maka dapat diambil kesimpulan antara lain:

A. Deskripsi variabel kualitas produk dapat disimpulkan bahwa kualitas produk pada Madlyson di Distro Aztekline Tulungagung memiliki kualitas yang bagus, hal ini dapat berpengaruh pada keputusan pembelian konsumen pada produk tersebut.

Deskripsi variabel harga dapat disimpulkan bahwa harga produk pada Madlyson di Distro Aztekline Tulungagung yang ditawarkan dapat dijangkau semua kalangan serta harga yang ditawarkan lebih murah dibandingkan dengan produk lain sehingga dapat mempengaruhi keputusan pembelian konsumen.
Deskripsi variabel citra merek memiliki nilai yang tertinggi diantara variabel yang lain, hal ini berarti pengaruh citra merek sangat mempengaruhi keputusan pembelian masyarakat Tulungagung dan sekitarnya, dengan citra merek yang mempunyai cirri khas tersendiri dan mudah diingat oleh masyarakat sehingga dapat mempengaruhi konsumen untuk melakukan transaksi pembelian.

B. Model yang di gunakan yaitu regresi linier berganda dapat menerangkan pengaruh kualitas produk, harga dan citra merek terhadap terhadap keputusan pembelian produk madlyson di distro aztekline tulungagung.

Model regresi linier berganda dengan pengujian uji t diketahui bahwa variabel citra merek merupakan variabel yang berpengaruh dominan terhadap keputusan pembelian produk madlyson di distro aztekline tulungagung.

\section{SARAN}

Berdasarkan kesimpulan yang telah dilakukan maka saran yang dapat diberikan dalam penelitian ini yaitu:

1. Bagi Perusahaan

Untuk meningkatkan keputusan pembelian produk madlyson di distro aztekline tulungagung, hendaknya lebih menitikberatkan pada kegiatan yang bertujuan untuk meningkatkan citra merek agar merek madlyson lebih dikenal lagi dibenak konsumen, misalnya dengan endorse salah satu artis atau orang yang mudah untuk menjadi sorotan dikalangan anak muda dan apabila ingin memperluas/ menambah pangsa pasar hendaknya memperhitungkan kualitas produk, harga, citra merek serta lokasi yang tepat, agar dapat menarik keputusan pembelian konsumen.

2. Bagi penelitian selanjutnya

Penelitian-penelitian lebih lanjut, hendaknya menambahkan variabel penghubung yakni motivasi yang belum ada pada penelitian ini

\section{REFERENSI}


Augusty, Ferdinand. 2006. Metode Penelitian Manajemen. Semarang: Badan Penerbit Universitas Diponegoro.

Arikunto, Suharsimi. 2002. Metodologi Penelitian. Jakarta: Rineka Cipta.

David L. goetsch dan Stanley B. Davis. (2002). Pengantar Manajemen Mutu 2, Ed. Bahasa Indonesia, Jakarta: PT Prenhalindo.

Freddy Rangkuti.2003.Teknik Mengukur dan Strategi Meningkatkan Kepuasan Konsumen. Jakarta: PT. Gramedia Pustaka.

Fandy Tjiptono. 2006. Manajemen Jasa. Edisi Pertama. Yogyakarta: Andi

Fandy Tjiptono dan Gregorius Chandra, (2005), Manajemen Kualitas Jasa, Yogyakarta: Andi

Ghozali, Imam. 2011. "Aplikasi Analisis Multivariate Dengan Program SPSS". Semarang: Badan Penerbit Universitas Diponegoro.

Kotler, Philip dan Gary Armstrong, 2001, Prinsip-prinsip Pemasaran, Jilid 1,Edisi Kedelapan,Jakarta,Erlangga.

Kotler, Philip and Gary Armstrong. 2008. Prinsip-prinsip Pemasaran. Edisi12. Jilid 1. Jakarta: Erlangga.

Kotler, Philip and Gary Armstrong. 2012. PrinsiprinsipPemasaran. Edisi13. Jilid 1. Jakarta: Erlangga.

Lupiyoadi, Hamdani. 2006. Manajemen Pemasaran Jasa, Edisi Kedua. Jakarta: Penerbit Salemba Empat.

Sugiyono. 2012 Metode Penelitian Bisnis. Bandung: Alfabeta.

Sutisna. 2003. Perilaku Konsumen dan Komunikasi Pemasaran. Bandung: PT Remaja Rosdakarya. 